\title{
Biomass and mineralmass estimates in a "cerrado" ecosystem
}

\author{
WELINGTON BRAZ CARVALHO DELITTI ${ }^{1,2}$, MARICO MEGURO ${ }^{1}$ and \\ JULI GARCIA PAUSAS ${ }^{2}$
}

(received: September 22, 2005; accepted: August 24, 2006)

\begin{abstract}
Biomass and mineralmass estimates in a "cerrado" ecosystem). This work aimed to develop allometric equations for tree biomass estimation, and to determine the site biomass in different "cerrado" ecosystems. Destructive sampling in a "campo cerrado" (open savanna) was carried out at the Biological Reserve of Moji-Guaçu, State of São Paulo, southeastern Brazil. This "campo cerrado" (open savanna) grows under a tropical climate and on acid, low nutrient soils. Sixty wood plants were cut to ground level and measurements of diameter, height and weight of leaves and stems were taken. We selected the best equations among the most commonly used mathematical relations according to $\mathrm{R}^{2}$ values, significance, and standard error. Both diameter (D) and height $(\mathrm{H})$ showed good relationship with plant biomass, but the use of these two parameters together $\left(\mathrm{DH}\right.$ and $\left.\mathrm{D}^{2} \mathrm{H}\right)$ provided the best predictor variables. The best equations were linear, but power and exponential equations also showed high $\mathrm{R}^{2}$ and significance. The applicability of these equations is discussed and biomass estimates are compared with other types of tropical savannas. Mineralmass was also estimated. "Cerrados" proved to have very important carbon reservoirs due to their great extent. In addition, high land-use change that takes place nowadays in the "cerrado" biome may significantly affect the global carbon cycle.
\end{abstract}

Key words - allometry, carbon, "cerrados", nutrient, savannas

RESUMO - (Estimativas de biomassa e mineralomassa em um ecossistema de cerrado). O objetivo deste trabalho foi a obtenção de modelos matemáticos para estimar a biomassa arbórea aérea de cerrados e sua aplicação para diferentes tipos de ecossistemas deste bioma. Uma amostragem destrutiva foi realizada na Reserva Biológica de Moji-Guaçu, Estado de São Paulo, Sudeste do Brasil. Este campo cerrado está estabelecido sob clima tropical e sobre solos ácidos e distróficos. Os dados básicos foram obtidos por uma amostragem envolvendo medidas e o corte de 60 plantas ao nível do solo e a pesagem de caules e folhas separadamente. Foram selecionadas as melhores equações preditivas, de acordo com $\mathrm{R}^{2}$, significância e erro padrão. Diâmetros (D) e alturas (H) mostraram-se bons preditores da biomassa e o uso de ambos $\left(\mathrm{DH}, \mathrm{D}^{2} \mathrm{H}\right)$ resultou nas equações mais adequadas. A aplicabilidade destas equações foi discutida e os valores de biomassa comparados com outros estudos. A mineralomassa foi também determinada. Os cerrados são importantes reservatórios de carbono devido à sua grande extensão. As grandes alterações da cobertura vegetal dos cerrados, que são transformados em sistemas de pecuária e agricultura (soja), deverão resultar em significativo efeito no ciclo global de carbono.

Palavras-chave - alometria, carbono, cerrado, savanas, nutrientes

\section{Introduction}

Brazilian ecosystems may have a significant role in global carbon balance due to their great extent (i.e. $4 \%-5 \%$ of global C emissions, according to Schoeder \& Winjum 1995), but accurate carbon storage and fixation rates cannot be evaluated due to the lack of appropriate biomass estimations for each type of ecosystem. Amazonia has been the most studied Brazilian biome (Araújo et al. 1999, Fearnside 1996, Fearnside 1997, Kauffman et al. 1994, Nelson et al. 1999, Laurence

1. Universidade de São Paulo, Instituto de Biociências, Departamento de Ecologia Geral, Caixa Postal 11461, 05422-970 São Paulo, SP, Brazil.

2. Centro de Estudios Ambientales del Mediterráneo (CEAM), Parque Tecnológico, Charles Darwin 14, 46980 Paterna, Valencia, Espanha.

3. Corresponding author: delitti@ib.usp.br et al. 1999), however accurate and reliable biomass studies for other ecosystems are needed. Brazilian "cerrados" are the second largest Brazilian biome; they cover about 1.8 million $\mathrm{km}^{2}$, and constitute the largest part of the neotropical savannas. "Cerrados" present a distinctive, rich flora with more than one thousand tree species and more than 2500 herb ( $>250$ grass) species (Eiten 1963, 1972, Coutinho 1978, Klink et al. 1994, Castro \& Kauffman 1998). Its biomass evaluation is very important since fire and land-use changes (agriculture) may translate into significant sources of greenhouse gases (Abdala et al. 1998, Castro \& Kauffman 1998).

"Cerrados" grow under a tropical climate and comprise a mosaic of ecosystems with large variations in structure and biomass. Tree and shrub size and density are the main aspects in the diversification of the "cerrado" into the different physiognomic types 
(Coutinho 1990), and this diversification have been attributed to differences in soil properties and fire regime (Goodland 1971, Lopes \& Cox 1977, Coutinho 1978, Kauffman et al. 1994). The different "cerrado" types range from herbaceous treeless ecosystems ("campo limpo") to forests ("cerradão"), with intermediate types often called: "campo sujo", "campo cerrado" and "cerrado sensu stricto" (Coutinho 1978).

Plant biomass depends on biota interactions with the environment, and its variation is suggestive of the magnitude of the factors affecting each ecosystem (Pivello \& Coutinho 1992). Herbaceous-layer biomass presents differences among sites, season, and fire regime (Pivello \& Coutinho 1992, Pivello \& Coutinho 1996). However, there are very few data on the biomass of the woody components (trees and shrubs) in these types of ecosystems. Two studies in Central Brazil showed great variation among some types of "cerrados" and a large portion of belowground biomass. Abdala (1998) estimated tree biomass using an unpublished equation, and Castro \& Kauffman (1998) used the model developed for moist tropical forests by Brown et al. (1989), because they did not find any specific equation for the "cerrado" species. Ottmar et al. (2001) presented a book for biomass and fuel estimates related to a stereo-photograph series and Resende \& Felfili (2004) discussed the carbon reservoir in "cerrado" sensu stricto from Central Brasil. This few amount of information limits knowledge on the global aspects of "cerrado" ecosystems, since woody components strongly reflect environmental quality due to their high nonproductive/ productive biomass ratio (Abdala et al. 1998, Castro \& Kauffman 1998, Ottmar et al. 2001).
The purpose of this work is to provide general allometric equations for estimating "cerrado" tree biomass and to determine "cerrado" biomass and mineralmass using these equations and the nutrients contents present in the vegetation. We intend to analyse and establish the relations between the biomass of the aboveground elements and the size of the woody plant components of the vegetation (diameter and height), and represent them by equations. Such models will permit rapid and non-destructive biomass estimation in multispecies tropical savanna ecosystems. The equations may be useful for other studies, such as those on nutrient cycling, carbon storage, gradient analyses, fire effects, land-use change, and remote-sensing analyses in the "cerrado" region.

\section{Materials and methods}

Study area - Sampling was carried out at the Mogi Guaçu Biological Reserve (22 $11^{\prime}$ S $-22^{\circ} 18^{\prime}$ S and $47^{\circ} 07^{\prime} \mathrm{W}-43^{\circ} 13^{\prime} \mathrm{W}$ ), of the Institute of Botany, State of São Paulo. The reserve has 343 ha covered mainly by "cerrado" and strips of gallery forests bordering the Moji-Guaçu River. Pine plantations surround the reserve (Gibbs et al. 1983). The altitude ranges from 560 to $700 \mathrm{~m}$ and the relief is flat to gently rolling (Eiten 1963). The climate of the region is Tropical, type II, according to Walter et al. (1976), with a clearly rainy summer and a mild and dry winter. The mean annual temperature and rainfall are $20.8^{\circ} \mathrm{C}$ and $1.359 \mathrm{~mm}$, respectively (Burger \& Delitti 1999, De Vuono et al. 1986).

The soil is red-yellow latosol (oxisol), sandy-phase (LVa), deep (10-20 m), and well-drained with low fertility. It contains well-developed $\mathrm{Al}$, and the $\mathrm{pH}$ range is from 4 to 5 (Oliveira et al. 1982). The soil contains low nutrient concentrations and amounts in the first meter soil-layer and the values

Table 1. Soil nutrient concentrations and soil mineralmass in the "campo cerrado" (Moji-Guaçu, SP, Brazil). Data are mean values from 10 replicates. All data refer to the total available form in the mineral soil. Data from Delitti (1998).

\begin{tabular}{|c|c|c|c|c|c|c|}
\hline \multirow[b]{2}{*}{ Soil layer } & \multicolumn{3}{|c|}{ Nutrient concentration $\mathrm{mg} \mathrm{kg}^{-1}$} & \multicolumn{3}{|c|}{ Soil mineralmass kg ha ${ }^{-1}$} \\
\hline & $0-33 \mathrm{~cm}$ & $34-67 \mathrm{~cm}$ & $68-100 \mathrm{~cm}$ & $0-33 \mathrm{~cm}$ & $34-67 \mathrm{~cm}$ & $68-100 \mathrm{~cm}$ \\
\hline $\mathrm{N}$ & 49.34 & 8.77 & 6.15 & 230.27 & 35.08 & 24.6 \\
\hline $\mathrm{P}$ & 3.62 & 0.86 & 0.86 & 16.88 & 3.44 & 3.44 \\
\hline K & 65.17 & 7.82 & 3.91 & 304.11 & 31.28 & 15.64 \\
\hline $\mathrm{Ca}$ & 71.48 & 22.04 & 22.04 & 333.55 & 88.16 & 88.16 \\
\hline $\mathrm{Mg}$ & 27.96 & 7.29 & 6.08 & 130.48 & 29.16 & 24.32 \\
\hline $\mathrm{Fe}$ & 94.47 & 14.35 & 7.18 & 440.88 & 57.40 & 29.76 \\
\hline $\mathrm{Cu}$ & 1.57 & 1.11 & 1.00 & 7.28 & 4.44 & 4.00 \\
\hline $\mathrm{Zn}$ & 1.25 & 0.24 & 0.18 & 5.85 & 0.96 & 0.72 \\
\hline $\mathrm{Al}$ & 146.24 & 42.25 & 31.66 & 682.43 & 196.00 & 125.84 \\
\hline
\end{tabular}


decrease from the surface to deeper soil-layer (table 1, Delitti 1998).

In a study of the various physiognomic types of "cerrados" present in the area (Gibbs et al. 1983), 107 woody species were recorded. Tree heights range from 4.5 to $6 \mathrm{~m}$ in the most closed savanna ("cerradão"), and from 2.6 to $3.6 \mathrm{~m}$ in a more open type ("campo cerrado").

Detailed vegetation surveys were developed in this Reserve by Eiten (1963) and Gibbs et al. (1983). Some of the most abundant shrub and tree species are: Acosmium dasycarpum (Vog) Yacovl., Annona coriacea Mart., Aspidosperma tomentosum Mart., Byrsonina verbascifolium (Spr.) Kunth., B. coccolobifolia (Spr.) Kunth, Caryocar brasiliensis Camb., Dimorphandra mollis Benth., Erythroxylum suberosum A. St-Hil., Kielmeyera coriacea (Spr.) Mart., Miconia albicans Cogn, Ouratea spectabilis A. St-Hil., Qualea grandiflora Mart., Strychnos pseudoquina A. St.-Hil. and Stryphnodendrom adstringens (Mart.) Coville.

At this reserve the cerrado ecosystems are protected from fire since the 70's but, some accidental fires occurred in the previous years.

A quantitative vegetation survey was made using the point-dentred quarter method (Curtis \& Cottan 1965) in order to determine species frequency, as well as the height $(\mathrm{H})$ and basal diameter (D) distribution among the woody plants. A linear transect was established according to the longer axis of the area (about $10 \mathrm{ha}$ ), and 60 sampling points were taken along this transect. The diameter and height were measured and the species identified for 240 woody individuals (shrubs and trees) with basal diameter equal to or greater than $2.5 \mathrm{~cm}$, in order to sample only woody species. From this group, 60 individuals, covering the ranges of diameters and heights observed in the community, were cut down to ground level. These measurements were carried out at the end of the rainy summer, in order to obtain maximum leaf and total biomass accumulation data. The selected individuals belonged to 32 species and most of these species were present in a frequency higher than $30 \%$ of the sample (Gibbs et al. 1983).

The stems and leaves were separated for each individual, and the fresh weight of each fraction was measured in the field using a dynamometer. Samples of trunks and leaves from each selected individual were taken to the laboratory, dried at $80^{\circ} \mathrm{C}$ to constant weight, and the relation between their fresh and dry weights used for biomass estimates. The belowground biomass was not sampled in this work.

The mathematical relations most frequently used in forest biomass allometric analysis were tested to find the relationship between the predictive variables and the tree biomass (Catchpole \& Wheeler 1992, Brown et al. 1989, Martinez-Yrizar et al. 1992, Burger \& Delitti 1999). We analysed the most common types of equations referred to in the literature for reflecting different response shapes (linear, quadratic, power, and exponential) and selected the best ones, according to their significance and standard error, and $\mathrm{R}^{2}$ when variables and type of equations were similar.
In addition, we compared the predicted biomass values with the observed values, in order to evaluate the efficiency of each equation. For all procedures the dependent variables were total biomass, stem biomass, and leaf biomass (in $\mathrm{g}$ of dry weight). As independent variables, we tested the following parameters: diameter $(\mathrm{D})$, height $(\mathrm{H})$ and different combinations of both.

We estimated the site biomass in the Reserve $\left(\mathrm{Mg} \mathrm{ha}^{-1}\right)$ using the selected equations and the independent variables (density, diameter, and height distribution) observed in same area. Site biomass was also estimated by Satoo's method (Satoo 1970), that is, multiplying the sum of weights of the sampled trees $\left(w_{\mathrm{i}}\right)$ by the ratio between the basal area $(B A)$ observed in the ecosystem and the sum of the basal areas of the sampled individuals $\left(b a_{\mathrm{i}}\right)$, according to the equation:

$$
\text { Total Site Biomass }=\sum_{i=1}^{n} w_{i} \times\left(\frac{B A}{\sum_{i=1}^{n} b a_{i}}\right),
$$

where $n$ is the number of individuals sampled.

We also used this method for estimating site biomass in other types of cerrado from basal area data presented in the literature (Goodland 1971, Coutinho 1990, Abdala et al. 1998, Castro \& Kauffman 1998).

Samples of leaves and stems from each cut plant were sent for nutrient content analysis. The samples were ground, and 10 subsamples were analysed with 3 replicates each. The analyses were carried out at the CENA - Centro para a Energia Nuclear na Agricultura (University of São Paulo). The methods used were: emission spectrometry (Induced argon plasma) for P, Ca, Mg, Fe, Cu, Mn, B and Zn (Jørgensen 1977); colorimetry for total N (Jørgensen 1977); atomic absorption for K (Zagatto et al. 1979) and turbidimetry for S (Krug et al. 1977).

The nutrient concentration values ( $\mathrm{mg} \mathrm{g}^{-1}$ or $\mathrm{mg} \mathrm{kg}^{-1}$ ) were used for mineralmass (nutrient mass $\mathrm{kg} \mathrm{ha}^{-1}$ or $\mathrm{mg} \mathrm{ha}^{-1}$ ) estimation, using the biomass values previously obtained. Woody plant mineralmass values was compared to the amounts observed in other compartments (herb layer, belowground biomass and soil) of the same ecosystem (data from Delitti 1998), in order to evaluate de relative importance of each one in the storage of nutrients.

\section{Results}

The diameters and heights observed in the Reserve ranged from $2.5 \mathrm{~cm}$ and $1 \mathrm{~m}$ to maximum values of $25 \mathrm{~cm}$ and $6.7 \mathrm{~m}$, respectively; consequently, these are the limits of applicability for the equations developed in this study. Woody plant biomass varied from $174.32 \mathrm{~g}$ to $125.7 \mathrm{~kg}$, and stem biomass comprised more than $93 \%$ of total biomass. During dry season leaf biomass may be smaller. 
Table 2. Proportion of leaf to total biomass observed in "campo cerrado", by diameter classes (Moji-Guaçu, SP, Brazil).

\begin{tabular}{cc}
\hline Diameter class $(\mathrm{cm})$ & Leaf/Total $(\%)$ \\
\hline $2.5-5.0$ & 22.0 \\
$5.1-10.0$ & 9.5 \\
$10.1-15.0$ & 7.5 \\
$15.1-20.0$ & 4.6 \\
$20.1-25.0$ & 4.2 \\
\hline
\end{tabular}

The ratio between leaf and total biomass decreased according to increasing diameter (table 2), although absolute leaf biomass values increased with tree size. For leaf biomass, the rate of increment according to tree size was smaller than for stem and total biomass, as shown by the coefficient values in the equations (table 3).

Both diameter and height showed a good relationship with plant biomass, and we present the best equation that considered these variables independently (table 3 ). Most vegetation surveys present only one of these parameters, and these equations may be used for biomass estimation because of their high $\mathrm{R}^{2}$ and significance (they explain more than $76 \%$ of the variation observed in total and stem biomass). Diameter was better related to biomass than height, as is showed by the $\mathrm{R}^{2}$ values, but both equations display a good fit. The use of diameter and height together as independent variable results in the best equations ( 7,8 and 9 in table 3 ) for predicting biomass, according to all criteria (table 3 ). Linear equations best described the overall relation between biomass, diameter, and height together (table 3). The $\mathrm{R}^{2}$ values were lower for leaves, although they still showed a significant relation. So, leaf biomass values can be obtained using the equation, but the explained variances are from $53 \%$ to $62 \%$, and the error is greater.

Site biomass estimates $\left(\mathrm{Mg} \mathrm{ha}{ }^{-1}\right.$, table 4$)$ were obtained using the equations in table 3 and the vegetation data obtained in the same ecosystem. Equations using diameter only $(1,2,3)$ predicted smaller biomass values than equations using height only $(4,5,6)$; However, the best equations (i.e. using $\mathrm{D}$ and $\mathrm{H}$ together; $7,8,9$ ) predicted the highest values. These latter equations also predicted the biomass values more similar to those observed directly in field sample.

Nutrient concentrations observed in "campo cerrado" vegetation (table 5) were used to estimate the amounts of elements stored in this vegetation (table 6).

Table 3. Selected equations for total, stem and leaf biomass $(\mathrm{g})$ in Brazilian cerrados. X represents Diameter $(\mathrm{D}=\mathrm{cm}), \mathrm{Height}(\mathrm{H}$ $=\mathrm{m})$, Diameter per Height $(\mathrm{DH})$, Squared Diameter per height $\left(\mathrm{D}^{2} \mathrm{H}\right)$. A and B are the regression coefficients (with standard error in brackets), and $F$ and $\mathrm{S}$ are the $F$-statistic and the standard error (s.e.) from the ANOVA table. All equations are significant at $P<0.00001$.

\begin{tabular}{|c|c|c|c|c|c|c|c|}
\hline Equation & Biomass & $X$ & A (s.e.) & B (s.e.) & $\mathrm{R}^{2}$ & $F$ & S \\
\hline $1^{1}$ & Total & $\mathrm{D}$ & $\begin{array}{c}32.86 \\
(8.64)\end{array}$ & $\begin{array}{c}2.47 \\
(0.13)\end{array}$ & 0.878 & 372.97 & 0.54 \\
\hline $2^{1}$ & Stem & $\mathrm{D}$ & $\begin{array}{l}20.23 \\
(5.32)\end{array}$ & $\begin{array}{c}2.63 \\
(0.13)\end{array}$ & 0.890 & 422.73 & 0.54 \\
\hline $3^{1}$ & Leaf & $\mathrm{D}$ & $\begin{array}{c}21.44 \\
(8.67)\end{array}$ & $\begin{array}{c}1.54 \\
(0.20)\end{array}$ & 0.541 & 61.34 & 0.83 \\
\hline $4^{3}$ & Total & $\mathrm{H}$ & $\begin{array}{l}207.11 \\
(51.73)\end{array}$ & $\begin{array}{c}0.977 \\
(0.07)\end{array}$ & 0.772 & 175.78 & 0.73 \\
\hline $5^{3}$ & Stem & $\mathrm{H}$ & $\begin{array}{l}149.65 \\
(40.19)\end{array}$ & $\begin{array}{c}1.03 \\
(0.08)\end{array}$ & 0.764 & 168.41 & 0.79 \\
\hline $6^{3}$ & Leaf & $\mathrm{H}$ & $\begin{array}{c}61.14 \\
(17.44)\end{array}$ & $\begin{array}{c}0.64 \\
(0.08)\end{array}$ & 0.537 & 58.06 & 0.84 \\
\hline $7^{2}$ & Total & $\mathrm{D}^{2} \mathrm{H}$ & & $\begin{array}{c}28.77 \\
(0.79)\end{array}$ & 0.961 & 1283.12 & 4359.40 \\
\hline $8^{2}$ & Stem & $\mathrm{D}^{2} \mathrm{H}$ & & $\begin{array}{c}27.81 \\
(0.67)\end{array}$ & 0.962 & 1733.50 & 4175.72 \\
\hline $9^{2}$ & Leaf & DH & 210.93 & $\begin{array}{l}17.63 \\
(1.41)\end{array}$ & 0.624 & 218.55 & 470.09 \\
\hline
\end{tabular}

${ }^{1} Y=a x^{b} ;{ }^{2} Y=a+b x ;{ }^{3} Y=a e^{b x}$ 
Table 4. Estimations of aboveground woody biomass in the "campo cerrado" (Moji-Guaçu, SP, Brazil), using equations in table 3 ( $\mathrm{X}=$ predictive variable; $\mathrm{D}=$ Diameter; $\mathrm{H}=$ Height $)$.

\begin{tabular}{cccc}
\hline Equations & Biomass & $\mathrm{X}$ & $\begin{array}{c}\text { Biomass } \\
\left(\mathrm{Mg} \mathrm{ha}^{-1}\right)\end{array}$ \\
\hline 1 & Total & $\mathrm{D}$ & 17.4 \\
2 & Stem & $\mathrm{D}$ & 16.7 \\
3 & Leaves & $\mathrm{D}$ & 1.0 \\
4 & Total & $\mathrm{H}$ & 18.5 \\
5 & Stem & $\mathrm{H}$ & 17.3 \\
6 & Leaves & $\mathrm{H}$ & 1.1 \\
7 & Total & $\mathrm{D}^{2} \mathrm{H}$ & 19.5 \\
8 & Stem & $\mathrm{D}^{2} \mathrm{H}$ & 18.1 \\
9 & Leaves & $\mathrm{DH}$ & 1.6 \\
\hline
\end{tabular}

Woody plants stored greater nutrient amounts than the herb layer and the litter, but the soil was the greatest reservoir of all elements due to its greater mass (table 6). We applied Satoo's (Satoo 1970) method, where the value of the site basal area obtained in this ecosystem (B.A. $=11.51 \mathrm{~m}^{2} \mathrm{ha}^{-1}$ ) was related to the sum of the basal area observed in the sampled plants (b.a. $=0.4251 \mathrm{~m}^{2}$ ). The obtained ratio was then related to the sum of the biomass $(828.95 \mathrm{~kg})$ observed in the sampled plants. This analysis resulted in the following relation:

Site Biomass $\left(\mathrm{Mg} \mathrm{ha}^{-1}\right)=1.95 \times$ Site Basal Area $\left(\mathrm{m}^{2} \mathrm{ha}^{-1}\right)$

Woody biomass estimations obtained for various physiognomic types of cerrados according to this method were compared with values provided by other authors, using different methods. Biomass values reflected physiognomic differences (table 8).

\section{Discussion}

Both diameter and height were good estimators of tree biomass, but the differences in woody density and the low relationship between diameter and height made $\mathrm{R}^{2}$ values lower than in equations that consider diameter and height together. This has been observed by various authors, probably because these parameters are the same ones used to calculate trunk volumes (Brown et al. 1989, Araújo et al. 1999). Moreover, the combination of both independent variables brought more real information about the ecosystem (i.e. size of plants) to the equation (Brown et al. 1989). Both linear and power equations using $\mathrm{D}$ and $\mathrm{H}$ together presented the highest $\mathrm{R}^{2}$ values, but the power model showed lower estimates for site biomass as compared to the field data (table 4).

Height showed less relationship with total biomass than diameter (table 3), since it is highly variable among the woody individuals, especially in the cerrados subjected to frequent disturbances, such as recurrent fires. Even so, the site biomass estimated by equations using $\mathrm{H}$ were similar to those obtained by the best equations (table 4). This may be due to the fact that site biomass is more dependent on biomass estimation of large trees, which are better estimated by height than by diameter. The observed variable architecture of the cerrado tree species, cause great variability in the biomass values of the same height class.

Biomass estimations using Satoo's (Satoo 1970) method (table 8) may present problems of over or underestimation of the real values, since the same basal area value may result from different sets of plants with different diameter distributions. However, the basal area was the only available variable in the different cerrado

Table 5. Nutrient and aluminium $\left(\mathrm{Al}^{+}\right)$concentrations in "campo cerrado" woody vegetation (Moji-Guaçu, SP, Brazil). Values are mean of ten replicates. Standard deviations are in brackets.

\begin{tabular}{|c|c|c|c|c|c|c|}
\hline \multicolumn{7}{|c|}{ Macronutrient $\left(\mathrm{mg} \mathrm{g}^{-1}\right)$} \\
\hline & $\mathrm{N}$ & $\mathrm{P}$ & $\mathrm{K}$ & $\mathrm{Ca}$ & $\mathrm{Mg}$ & $\mathrm{S}$ \\
\hline Stems & $8.8(0.44)$ & $0.6(0.07)$ & $3.0(0.45)$ & $2.1(0.35)$ & $0.7(0.09)$ & $0.6(0.08)$ \\
\hline Leaves & $18.4(1.1)$ & $1.0(0.1)$ & $6.9(0.89)$ & $5.8(1.15)$ & $2.1(0.42)$ & $2.3(0.33)$ \\
\hline \multicolumn{7}{|c|}{ Micronutrient $\left(\mathrm{mg} \mathrm{kg}^{-1}\right)$} \\
\hline & $\mathrm{Fe}$ & $\mathrm{Cu}$ & $\mathrm{Mn}$ & $\mathrm{Zn}$ & $\mathrm{B}$ & $\mathrm{Al}$ \\
\hline Stems & $132(19)$ & $5.0(0.8)$ & 84 (12) & $9(0.8)$ & $7(0.6)$ & $156(22)$ \\
\hline Leaves & $204(29)$ & $7.6(1.1)$ & $250(35)$ & $20(1.7)$ & $47(4.1)$ & $1334(192)$ \\
\hline
\end{tabular}


Table 6. Macro and micronutrients and aluminium $\left(\mathrm{Al}^{+}\right)$stored in the aboveground "campo cerrado" woody vegetation (Moji-Guaçu, SP, Brazil).

\begin{tabular}{|c|c|c|c|c|c|c|}
\hline & \multicolumn{6}{|c|}{ Macronutrient $\left(\mathrm{kg} \mathrm{ha}^{-1}\right)$} \\
\hline & $\mathrm{N}$ & $\mathrm{P}$ & $\mathrm{K}$ & $\mathrm{Ca}$ & $\mathrm{Mg}$ & $\mathrm{S}$ \\
\hline Stems & 195.4 & 13.3 & 66.6 & 46.6 & 15.5 & 13.3 \\
\hline Leaves & 27.6 & 1.5 & 10.4 & 8.7 & 3.2 & 3.5 \\
\hline \multirow[t]{3}{*}{ Total } & 223.0 & 14.8 & 77.0 & 55.3 & 18.7 & 16.8 \\
\hline & \multicolumn{6}{|c|}{ Micronutrient $\left(\mathrm{g} \mathrm{ha}^{-1}\right)$} \\
\hline & $\mathrm{Fe}$ & $\mathrm{Cu}$ & $\mathrm{Mn}$ & $\mathrm{Zn}$ & $\mathrm{B}$ & $\mathrm{Al}$ \\
\hline Stems & 2930.4 & 111.0 & 1864.8 & 199.8 & 155.4 & 3463.2 \\
\hline Leaves & 306.0 & 11.4 & 375.0 & 30.0 & 70.5 & 2001.0 \\
\hline Total & 3236.4 & 122.4 & 2239.8 & 229.8 & 225.9 & 5464.2 \\
\hline
\end{tabular}

Table 7. Nutrient and aluminum pools distribution in the "campo cerrado" (Moji-Guaçu, SP, Brazil).

\begin{tabular}{|c|c|c|c|c|c|c|c|c|c|c|c|}
\hline & \multicolumn{4}{|c|}{ Aboveground vegetation } & \multirow{2}{*}{\multicolumn{2}{|c|}{ Belowgroun biomass }} & \multirow{2}{*}{\multicolumn{2}{|c|}{ Litter layer }} & \multirow{2}{*}{\multicolumn{2}{|c|}{$\begin{array}{l}\text { Soil } \\
(1 \mathrm{~m})\end{array}$}} & \multirow[t]{2}{*}{ Total } \\
\hline & \multicolumn{2}{|c|}{ Woody } & \multicolumn{2}{|c|}{ Herbaceous } & & & & & & & \\
\hline & $\mathrm{kg} \mathrm{ha}^{-1}$ & $\%$ & $\mathrm{~kg} \mathrm{ha}^{-1}$ & $\%$ & $\mathrm{~kg} \mathrm{ha}^{-1}$ & $\%$ & $\mathrm{~kg} \mathrm{ha}^{-1}$ & $\%$ & $\mathrm{~kg} \mathrm{ha}^{-1}$ & $\%$ & $\mathrm{~kg} \mathrm{ha}^{-1}$ \\
\hline $\mathrm{N}$ & 223.0 & 31.4 & 8.5 & 1.2 & 112.0 & 15.8 & 76.2 & 10.7 & 290.0 & 40.9 & 709.7 \\
\hline $\mathrm{P}$ & 14.8 & 32.2 & 1.9 & 4.1 & 3.0 & 6.5 & 2.5 & 5.4 & 23.8 & 51.7 & 46.0 \\
\hline $\mathrm{K}$ & 77.0 & 16.9 & 13.9 & 3.1 & 8.8 & 1.9 & 4.1 & 0.9 & 351.0 & 77.2 & 454.8 \\
\hline $\mathrm{Ca}$ & 55.3 & 9.0 & 5.8 & 0.9 & 12.7 & 2.1 & 29.8 & 4.9 & 509.9 & 83.1 & 613.5 \\
\hline $\mathrm{Mg}$ & 18.7 & 8.7 & 3.0 & 1.4 & 4.0 & 1.9 & 5.8 & 2.7 & 184.0 & 85.4 & 215.5 \\
\hline $\mathrm{Fe}$ & 2.9 & 0.4 & 1.6 & 0.2 & 58.7 & 9.0 & 61.2 & 9.4 & 528.0 & 80.9 & 652.4 \\
\hline $\mathrm{Cu}$ & 0.1 & 0.6 & & & & & 0.1 & 0.6 & 15.7 & 98.7 & 15.9 \\
\hline $\mathrm{Zn}$ & 0.2 & 2.4 & 0.1 & 1.2 & 0.2 & 2.4 & 0.3 & 3.6 & 7.5 & 90.4 & 8.3 \\
\hline $\mathrm{Al}$ & 5.5 & 0.4 & 3.8 & 0.3 & 276.0 & 18.4 & 106.9 & 14.2 & 1004.3 & 66.8 & 1502.8 \\
\hline
\end{tabular}

Data from table 1; (Delitti 1998).

types. For this reason it was used as a rough estimation of their biomass, in spite of its limitations. There was agreement between the estimations made by our equations and Satoo's method for the "campo cerrado" of our study site (5 in table 8). The same can be said about the data from the "cerrado" of Brasilia where biomass was also estimated independently using another site-specific equation (6 in table 8; Abdala et al. 1998). On the other hand, the estimations did not agree with the values for other types of cerrados studied in Central Brazil (2, 8, 9 in table 8). This disagreement may be due to the limitations mentioned above, and it may also be due to the fact that Castro \& Kauffman (1998) used Brown et al. (1989) equation, which was developed for moist tropical forests. This equation seems to have limited application for Brazilian savannas, despite being widely used and considered very robust for moist forest ecosystems. Comparing our field values with those estimated by that equation for the same plants, we observe an underestimation of almost $40 \%$, and that error increased according to plant size.

Leaf biomass estimations are less accurate than stem and total biomass estimations, although similar tendencies were observed. The lower $\mathrm{R}^{2}$ values reflect the great crown heterogeneity in woody plants, even among individuals of the same species with similar diameter. Other factors, such as differences in leaf senescence time, leaf type, and morphological and anatomical differences, may influence the observed variance in leaf biomass. We suspect that these 
Table 8. Biomass estimated (from basal area values) and observed, in different types of Brazilian "cerrados".

\begin{tabular}{|c|c|c|c|c|}
\hline \multirow[t]{2}{*}{ Type of cerrado } & \multirow[t]{2}{*}{ Localization, State } & \multirow[t]{2}{*}{ Basal area $\left(\mathrm{m}^{2} \mathrm{ha}^{-1}\right)$} & \multicolumn{2}{|c|}{ Biomass $\left(\mathrm{Mg} \mathrm{ha}^{-1}\right)$} \\
\hline & & & Observed & Estimated \\
\hline Campo Sujo $^{1}$ & Triângulo Mineiro, MG & 3.0 & & 5.9 \\
\hline Campo Sujo ${ }^{4}$ & Brasília, DF & 4.3 & 1.7 & 8.4 \\
\hline Campo Cerrado ${ }^{1}$ & Triângulo Mineiro, MG & 7.6 & & 14.8 \\
\hline Campo Cerrado ${ }^{2}$ & Corumbataí, SP & 9.6 & & 18.7 \\
\hline Campo Cerrado ${ }^{5}$ & Mogi-Guaçu, SP & 11.5 & 19.5 & 22.4 \\
\hline Cerrado $^{3}$ & Brasília, DF & 14.5 & 26.0 & 28.3 \\
\hline Cerrado $^{1}$ & Triângulo Mineiro, MG & 16.8 & & 32.8 \\
\hline Cerrado Aberto ${ }^{4}$ & Brasília, DF & 19.6 & 12.8 & 38.2 \\
\hline Cerrado Denso ${ }^{4}$ & Brasília, DF & 20.5 & 16.1 & 40.0 \\
\hline 10) Cerradão $^{1}$ & Triângulo Mineiro, MG & 31.3 & & 61.0 \\
\hline
\end{tabular}

Data from ${ }^{1}$ (Goodland 1971); ${ }^{2}$ Coutinho 1990); ${ }^{3}$ (Abdala et al. 1998); ${ }^{4}$ (Castro \& Kauffman 1998); ${ }^{5}$ This study.

equations may underestimate leaf biomass, because a study of leaf litter production and an evaluation of leaf mortality by frost in the same area suggested greater real values (Delitti 1998). However, our results fall in the range found for other savannas such as the African Colophospermum mopane (J. Kirk ex Benth.) J. Leonard savanna (1.2 to $2.7 \mathrm{Mg} \mathrm{ha}^{-1}$, Dekker \& Smit 1996). Data obtained in sampling on leaf biomass according to diameter classes (table 2) may be useful for estimating the leaf compartment in cerrado ecosystems. The leaf/stem biomass ratio increases with decreasing plant size, and this proportion is even greater in the herbaceous layer, which showed a leaf/ stem ratio of about 0.5 in the same Reserve (Delitti 1998).

Biomass values found for Brazilian "cerrados" are comparable to those found for other tropical savannas, such as some African ones: The open and the dense shrub savannas of Ivory Coast presented 22 and $33 \mathrm{Mg} \mathrm{ha}^{-1}$, respectively (Menaut 1982). The Burkea africana Hook savannas (South Africa) showed values from 16 to $22 \mathrm{Mg} \mathrm{ha}^{-1}$ (Rutherford 1983), and in the Miombo woodland (Zimbabwe) the biomass was $23 \mathrm{Mg}$ ha $^{-1}$ (Guy 1981). The great variation in biomass - up to tenfold - (table 8), observed between the different types of the "cerrados" is suggestive of the magnitude of the driving forces controlling the development of these ecosystems. "Cerrados" grow on acidic nutrient-poor soils and are subjected to periodic fires and seasonal droughts. Additional disturbances, as well as variations in climate and edaphic factors, are the origin of the observed variations in ecosystem structure (Coutinho 1990, Goodland 1971, Lopes \& Cox 1977). Such variations were directly observed in Central Brazil (Castro \& Kauffman 1998) and also in other tropical savannas. For example, in the Ivory Coast, biomass ranged from $7.40 \mathrm{Mg} \mathrm{ha}^{-1}$, in ecosystems of scattered shrubs, to 54. $2 \mathrm{Mg} \mathrm{ha}^{-1}$ in woody savanna (Menaut 1982). In Zimbabwe, Guy (1981) observed biomass values from $23.03 \mathrm{Mg}^{-1}$ to $65.76 \mathrm{Mg} \mathrm{ha}^{-1}$ according to the development of the tree layer. A great variation was also observed among plots of a savanna in Kenya (Legilisho-Kiyiapi 1998).

In most savannas, the presence of trees implies biomass values higher than $10 \mathrm{Mg} \mathrm{ha}^{-1}$, but the total aboveground biomass is always lower than $100 \mathrm{Mg} \mathrm{ha}^{-1}$. In the "cerrado" domain there are strips of gallery forests along the rivers, where greater biomass is reached because of the higher water availability. For example, in a neighbouring area of our field site, a biomass of $133 \mathrm{Mg} \mathrm{ha}^{-1}$ was recorded in a gallery forest (Burger \& Delitti 1999, Delitti \& Burger 2000). Herbaceousgrassy savannas present biomass values lower than $10 \mathrm{Mg} \mathrm{ha}^{-1}$ (San José \& Medina 1976), with some exceptions, such as the values observed in an Andropogon savanna, with accumulation between 7 and $15 \mathrm{Mg} \mathrm{ha}^{-1}$ (Lamotte 1975).

The herbaceous layer of the Moji-Guaçu "campo cerrado" was estimated as $4.4 \mathrm{Mg} \mathrm{ha}^{-1}$ (Delitti 1998). Values from 4 to $8 \mathrm{Mg} \mathrm{ha}^{-1}$ have been record in Brazilian "cerrados" (Pivello \& Coutinho 1992). Comparing these with the values in tables 4 and 8 , one can verify that the woody layer, although discontinuous, is a major reservoir of organic matter. In "campo cerrado", woody biomass corresponds to $75 \%$ of the total. This proportion increases with increasing tree density, because trees 
have a suppressive effect on the grassy layer by shading (Coutinho 1978).

The mineral content was also greater in woody plants, and showed a longer mean cycling time than in herbs (Delitti \& Burger 2000). Woody plants stored a great portion of nutrients (table 7), especially N, P and $\mathrm{K}$, which are the most limiting elements for this ecosystem, due to its soil properties (acid, low fertility, low CEC - Cation Exchange Capacity, according to Oliveira et al. 1982). The vegetation and litter layer together showed a high proportion of the most limiting nutrients for plant growth (table 7). For the rest of the nutrients and $\mathrm{Al}$, accumulation in the soil compartment predominated, as usually happens in a wide range of ecosystems (Proctor 1983, Proctor 1989, Delitti \& Burger 2000)

The same was observed in a neighbouring gallery forest, but the concentrations and the amounts of nutrients were much greater than those found in the savanna (Delitti \& Burger 2000). Micronutrient concentrations and total content data are rare in the literature, and this lack of knowledge limits the possibility of comparisons or more complete analysis of these ecosystems (Davis-Brain 1997). Mineralmass observed in the "campo cerrado" is comparable to other savannas (Proctor 1989), and is much smaller than the values reported for tropical forests in many countries (Proctor 1983, Jordan 1985). Cerrados are nutrient-poor ecosystems and so any disturbance affecting the tree layer will result in important nutrient loss and the change towards a simpler type of ecosystem with a more open nutrient cycle (Delitti 1998, Delitti et al. 2001, Pivello \& Coutinho 1992, Pivello \& Coutinho 1996).

In the "cerrados", the grassy-layer is the most affected by fires at the short-term scale, but it stores only a small portion of total nutrient pool (table 7). It is known that, at mid or long-term scales, frequent fires may cause a progressive decline in tree and shrub densities (Coutinho 1990). "Cerrado" woody plants present smaller resilience than herbs to this disturbance, resulting in simpler communities and nutrient-deficient ecosystems, because a greater amount of nutrients is lost (table 7). Ecosystems affected by fire tend to respond with degradation toward more simple and less resilient systems due to losses in nutrient and energy reservoirs (Delitti et al. 2005, Ferran et al. 2005). Tropical savannas tend to xerophytic and pyrophytic vegetation dominated by grasses (Goldammer \& Price 1998, Pivello \& Coutinho 1992, Pivello \& Coutinho 1996). At "Cerrado de Emas" (Pirassununga, São Paulo State), an area of "campo cerrado" has been protected from fire since 1946. During the following years a great change in the ecosystem structure was observed, and after 20 years the area was transformed in the most closed cerrado type ("cerradão"). The neighbouring area that continued to be burnt at 1-to-2 year interval maintained the original open structure. Considering the data presented in table 8 for other closed cerrados, we can estimate that in the "Cerrado de Emas", at Pirassununga, recurrent fire prevented the biomass from increasing by approximately 3 times. Mineralmass was, similarly, kept much smaller due to the fire regime and consequent nutrient export (Pivello \& Coutinho 1992). These data show the great impact of fire on the tree layer and support the hypothesis presented by Coutinho $(1978,1990)$ concerning the role of fire in this biome.

All biomass studies carried out in the Brazilian savannas show that this biome is a very important carbon reservoir because of its great extent $(1,8$ millions $\mathrm{km}^{2}$ ). Intermediate types of savanna (from open to closed cerrado) that cover the major part (70\%) of this area have between 20 and $40 \mathrm{Mg} \mathrm{ha}^{-1}$ of total woody aboveground biomass (table 7). Considering the herbaceous layer, the total Brazilian "cerrado" biomass corresponded originally to about 2 to $4 \times 10^{9} \mathrm{Mg}$ of C stored. These values are probably underestimates, because the areas covered by the most closed ecosystem ("cerradão") are not included, and they contain much greater biomass. Moreover, belowground biomass in the "cerrados" may be greater than the aboveground portion (Abdala et al. 1998, Castro \& Kauffman, 1998, Delitti 1998, Delitti et al. 2001). "Cerrados" are very important biomass and carbon pools, and the current changes in these ecosystems will likely have a significant effect on the global carbon balance. Nowadays, human impacts make the cerrados the most disturbed and transformed of all Brazilian ecosystems, with a yearly deforestation rate of about $20,000 \mathrm{~km}^{2}$ (almost 1\% of its original area; (Klink et al. 1994). Fire and land use changes are widespread and may transform cerrados and other vast areas in important source of greenhouse gases, and significantly reduce the carbon sink capacity of terrestrial ecosystems. Besides Amazonia, other Brazilian ecosystems need to be considered in global change studies using reliable biomass data.

Acknowledgements - The present study has been partially financed by Fapesp (97/3612-2) and CNPq (301741/1983-2). The Reserva Biológica e Estação Experimental de Moji-Guaçu, IBt, 
SMA/SP supported field work. We thank Ramón Vallejo for his valuable comments on an early draft of this manuscript. Jackie Scheidding provided English review. We are indebted to P.C. Fernandes and Patricia G.M. Cesário for their important help. W. Delitti also thanks his colleagues at CEAM and the people of Spain for their fine hospitality. Welington dedicates this article to the memory of "Bety", Isabel Maria Carvalho Delitti, beloved sister, daughter, mother, aunt and grandma and a fine Science teacher at Penápolis, SP.

\section{References}

ABDALA, G.C., CALDAS, L.S., HARIDASAN, M. \& EITEN, G. 1998. Above and belowground organic matter and root:shoot ratio in a cerrado in Central Brazil. Brazilian Journal of Ecology 2:11-23.

ARAÚJO, T.M., HIGUCHI, N., CARVALHO JUNIOR, J.A. 1999. Comparison of formulae for biomass content determination in a tropical rain forest site in the State of Pará, Brazil. Forest Ecology and Management 117:43-52.

BROWN, S., GILLESPIE, A.J.R. \& LUGO, A. 1989. Biomass estimation methods for tropical forests with application to forest inventory data. Forest Science 35:881-902.

BURGER, D.M. \& DELITTI, W.B.C. 1999. Fitomassa epigéia da Mata ciliar do rio Mogi Guaçu, Itapira, SP. Revista Brasileira de Botânica 22:429-435.

CASTRO, E.A. \& KAUFFMAN, J.B. 1998. Ecosystem structure in the Brazilian cerrado: a vegetation gradient of aboveground biomass, root biomass and consumption by fire. Journal of Tropical Ecology 14: 263-283.

CATCHPOLE, W.R. \& WHEELER, C.J. 1992. Review estimating plant biomass: a review of techniques. Australian Journal of Ecology 17:121-131.

COUTINHO, L.M. 1978. O conceito de cerrado. Revista Brasileira de Botânica 1:17-23.

COUTINHO L.M. 1990. Fire in the ecology of Brazilian cerrado. In Fire in the tropical biota (J.G. Goldmammer, ed.). Springer-Verlag, Berlin, p.82-105.

CURTIS, J. \& COTTAN, G. 1965. Plant Ecology Workbook. Burgess Publishing Company, Minneapolis.

DAVIS-BRAIN, E. 1997. Deficiences and toxicity of trace elements and micronutrients in tropical soils: limitations of knowledge and future research needs. Environmental Toxicology Chemistry 16:75-83.

DEKKER, B.R. \& SMIT, G.N. 1996. Browse production and leaf fenology of some trees and shrubs in different Colophospermum mopane savanna communities. African Journal Range Forage Science 13:15-23.

DELITTI, W.B.C. 1998. Ciclagem de nutrientes em cerrados. VIII Seminário Regional de Ecologia, Universidade Federal de São Carlos, São Carlos, p.1031-1045.

DELITTI, W.B.C. \& BURGER, D.M. 2000. Carbon and mineral nutrient pools in a gallery forest at Mogi Guaçu River, Southeast Brazil. Annals of Forestry Science 57:39-48.
DELITTI, W.B.C., PAUSAS, J. \& BURGER, D.M. 2001. Belowground biomass seasonal variation in two Neotropical savannahs (Brazilian Cerrados) with different fire histories. Annals of Forest Science 7:713-722.

DELITTI, W.B.C., FERRAN, A., TRABAUD, L. \& VALLEJO, R. 2005.Effects of fire recurrence in Quercus coccifera L. shrublands of the Valencia Region (Spain): I. plant composition and productivity. Plant Ecology 177:57-70.

DE VUONO, Y.S., BATISTA, E.A. \& FUNARI, F.L. 1986. Balanço hídrico na área da Reserva Biológica de MogiGuaçu, São Paulo-Brasil. Hoehnea, São Paulo 13:73-85.

EITEN, G. 1963. Habitat flora of Fazenda Campininha I. In Simpósio sobre o cerrado (M.G. Ferri, ed.). Editora da Universidade de São Paulo, São Paulo, p.179-231.

EITEN, G. 1972. The cerrado vegetation of Brazil. Botanical Review 38:201-341.

FEARNSIDE, P.M. 1996. Amazonian deforestation and global warming: carbon stocks in vegetation replacing Brazil's Amazon forest. Forest Ecology and Management 80:21-34.

FEARNSIDE, P.M. 1997. Wood density for estimating forest biomass in Brazilian Amazonia. Forest Ecology and Management 90:59-87.

FERRAN, A., DELITTI, W.B.C. \& VALLEJO, R. 2005. Effects of fire recurrence in Quercus coccifera L. shrublands of the Valencia Region (Spain): II. plant and soil nutrients. Plant Ecology 177:70-83.

GIBBS, P.E., LEITÃO FILHO, H.F. \& SHEPHERD, G.J. 1983. Floristic composition and community structure in an area of cerrado in SE Brazil. Flora 173:433-449.

GOLDAMMER, J.G. \& PRICE, C. 1998. Potential impact of climate change on fire regimes in the tropics based on MAGICC and GISS GMC - Derived lightning model. Climatic Change 39:273-296.

GOODLAND, R. 1971. A physiognomic analysis of the "Cerrado" vegetation of Central Brazil. Journal of Ecology 59:411-419.

GUY, P.R. 1981. Changes in biomass and productivity of woodlands in the Sengwa Wildlife research area, Zimbabwe. Journal of Applied Ecology 18:507-519.

JORDAN, J.F. 1985. Nutrient cycling in tropical forest ecosystems. John Wiley \& Sons, Chichester.

JØRGENSEN, S.S. 1977. Some methods used for routine chemical analysis. Laboratory manual. Centro de Energia Nuclear na Agricultura, Piracicaba.

KAUFFMAN, J.B., CUMMINGS, D.L. \& WARD, D.E. 1994. Relationship of fire, biomass and nutrient dynamics along a vegetation gradient in the Brazilian cerrado. Journal of Ecology 82:519-531

KLINK, C.A., MACEDO, R.H. \& MUELLER, C.C. 1994. Cerrado: Processo de ocupação e implicações para a conservação e utilização sustentável de sua diversidade biológica. WWF-Brasil Report, Brasília. 
KRUG, F.J., BERGAMIN FILHO, H., ZAGATTO, E.A.G. \& JORGENSEN, S.S. 1977. Rapid determination of sulphate in natural waters and plant digests by continuous flow injection turbidimetry. Analyst 102:503-508.

LAMOTTE, M. 1975. Structure and function of a tropical savanna ecosystem. In Tropical ecological systems: trends in terrestrial and aquatic research. (F.B. Golley \& E. Medina, eds.). Springer-Verlag, Berlin, p.179-222.

LAURENCE, W.F., FEARNSIDE, P.M., LAURANCE, S.G., DELAMONICA, P., LOVEJOY, T.E., MERONA, J.M.R., CHAMBERS, J.Q. \& GASCON, C. 1999. Relationship between soils and Amazon forest biomass: a landscapescale study. Forest Ecology and Management 118:127-138.

LEGILISHO-KIYIAPI, J. 1998. Influence of site, regeneration mechanisms and land-use induced factors on biomass production and dynamics of the woody vegetation in a semi-arid Acacia woodland, Baringo, Kenya. In Proceedings international symposium on assessment and monitoring of forests in tropical dry regions with special reference to gallery forests. (J. Imaña-Encinas \& C. Klein, eds.). Universidade de Brasília, Brasília, p.199-213.

LOPES, A.S. \& COX, F.R. 1977. Cerrado vegetation in Brazil: an edaphic gradient. Agronomic Journal 69:828-831.

MARTINEZ-YRIZAR, A., SARUKHAN, J., PEREZ-JIMENEZ, A., RINCON, E., MAASS, J.M., SOLIS-MAGALLANES, A. \& CERVANTES, L. 1992. Above-ground phytomass of a tropical deciduous forest on the coast of Jalisco, Mexico. Journal of Tropical Ecology 8:87-96.

MENAUT, J.C. 1982. Primary production. in tropical grazing land ecosystems. A state of knowledgement report prepared by Unesco/Unep/Fao. Natural Resources 16:122-145.

NELSON, B.W., MESQUITA, R. PEREIRA, J.L.G., SOUZA, S.G.A., BATISTA, G.T. \& COUTO, L.B. 1999. Allometric regressions for improved estimate of secondary forest biomass in the central Amazon. Forest Ecology and Management 117:149-167.

OLIVEIRA, J.B., MENK, J.R.F., BARBIERI, J.L., ROTTA, C.L. \& TREMOCOLDI, W. 1982. Levantamento pedológico semi-detalhado do Estado de São Paulo: Quadrícula de Araras. Boletim Técnico do Instituto Agronômico Campinas 71:88-94.
OTTMAR, R.D. VIHNANEK, R.E., MIRANDA, H.S., SATO, M.N. \& ANDRADE, S.M.A. 2001. Stereo Photo series for quantifying cerrado fuels in central Brazil. V1. General Technical Report. PNW-GTR-519. Nortwest Research Station, Portland.

PIVELLO, V.R. \& COUTINHO, L.M. 1992. Transfer of macronutrients to the atmosphere during experimental burnings in an open cerrado (Brazilian Savanna). Journal of Tropical Ecology 8:487-497.

PIVELLO, V.R. \& COUTINHO, L.M. 1996. Aqualitative model to assist in the management of Brazilian cerrados. Forest Ecology and Management 87:127-138.

PROCTOR, J. 1983. Mineral nutrient in tropical forests. Physical Geography 7:422-31.

PROCTOR, J. 1989. Mineral nutrients in tropical forest and savanna ecosystems. Blackwell, Oxford.

RESENDE, A.V. \& FELFILI, J.M. 2004 Avaliação do estoque de carbono do cerrado sensu strito do Brasil Central. Comunicações Técnicas florestais, v.6, n.2 Departamento de Engenharia florestal, Universidade de Brasília, Brasília.

RUTHERFORD, M.C. 1983. Growth rates, biomass and distribution of woody plant roots in Burkea africanaOchna pulchra savanna. Vegetatio 52:45-63.

SAN JOSÉ, J.J. \& MEDINA, E. 1976. Organic matter production in the Trachypogon savanna at Calabozo, Venezuela. Tropical Ecology 17:113-124.

SATOO, T. 1970. A Synthesis of studies by the harvest method. Primary production relations in temperate deciduous forest of Japan. Ecological Studies 1:55-70.

SCHOEDER, P.E. \& WINJUM, J.K. 1995. Assessing Brazil's carbon budget: I. Biotic carbon pools. Forest Ecology and Management 75:77-86.

WALTER, H., HARNICKELL, E. \& MUELLER-DOMBOIS, D. 1976. Climate diagram maps. Springer-Verlag, Berlin

WHITTAKER, R.H. \& MARKS, P.L. 1975. Methods of assessing terrestrial productivity. In Primary productivity of the biosfere (H. Leith \& R.H. Whittaker, eds.). Springer-Verlag, New York 55-118.

ZAGATTO, E.A.G., KRUG, F.J., BERGAMIN FILHO, H., JØRGENSEN, S.S. \& REIS, B.F. 1979. Merging zones in flow injection analysis. Part 2. Determination of $\mathrm{Ca}, \mathrm{Mg}$ and $\mathrm{K}$ in plant material by continuous flow injection Atomic absorption and flame emission spectrometry. Analytica Chimica Acta 104:79-284. 